\title{
Kullalla koristellusta lakkatyöstä
}

Talking about zoos as places where humans go to look at other beings without being seen themselves (because the animals in cages are too habituated to crowds, and too marginalised to be able to return a look, to see us) John Berger (2009) asks us to consider the event of being looked at, being seen, rather than obsessing over our own ability to see. This, he argues, will yield much needed perspective into ourselves: our positionality and our possibilities of being the kind of beings and individuals we are. In short: seeing and being seen produce knowledge of different things. As do all of the four possible combinations:

\author{
seeing and being seen / seeing and not being seen \\ not seeing and being seen / not seeing and not being seen
}

These degrees and positions of relational blindness are intriguing when discussed in connection with research practices: that is, methodologically. Instead of focusing on the researcher's gaze as is usual in qualitative research, we might want to ask What does being seen do to us as researchers? Being seen by children in particular. As researchers concerned with presence: What do the various degrees and positions of relational blindness produce in our research?

\section{seeing and not being seen}

Tracing the design and social life of cities Richard Sennett (1990) writes about a fear of exposure that he understands to have developed as part of the religious history of Christianity. A fear of being seen, but a wish to see nevertheless has fuelled the creation of spaces in our societies in which we are able to see, to gaze, but can remain invisible as individuals. Sennett locates these places in densely populated urban settings as bland, neutralising spaces in which people's differences dissolve. Shopping malls host displays of materials and of people, yet offer a refuge of blending in as a neutral, generalised customer individual with no real visibility as a person.

Methodologically this first position can be taken as the most traditional one. Researchers have for long relied both on their explicit ability to look/see (to gaze) and simultaneously on their own invisibility, rendering the objectivity of research to correlate with the degree of influence (visibility) by an individual researcher.

\section{not seeing and being seen}

The second position is familiar at least from Bentham's (1789) design and Foucault's (1977) discussion of the Panopticon: an arcithectural device in which an individual was seen (or believed that he/she was being seen, or the inability to know for sure whether one is seen or not) but remaining blind in that the source of the gaze one is subjected to is never visible. Ideas of 'surveillance' in general entail this visual bias of being seen but not seeing. In the dystopia by George Orwell in 1984 an ubiquitous, yet itself a somewhat invisible character, the Big Brother, is used as a symbol for (state) surveillance in which you are being watched but you don't know when, how, and by whom. 
Methodologically the idea that the researcher could remain an invisible Big Brother, begun to be bothered as qualitative research methodologies were established in the 1990s. The researcher was considered an active participant as well as an observer but the degrees of participation versus observing varied greatly (e.g., Schwartzman 1993). Not only unable to avoid being seen, it was eventually deemed that a researcher has to be seen to be able to do her job; that the researcher is her main methodological tool. To the extent that qualitative research has become almost synonymous with autoethnography. And so, brutally simplifying and provocating, research became about being seen as a researcher/individual, but not necessarily seeing much of other individuals when too busy reflecting one's own position.

\section{not seeing and not being seen / seeing and being seen}

Both cases - seeing and being seen, not seeing and not being seen - are without clear visually based tresholds. They are visually non-binary possibilities: there's no lopsidedness but either seeing/visibility or not seeing/invisibility of pretty much everyone and everything involved. As such these positions might dissolve the possibility for us to lean back to patterns of thinking and perceiving which follow the christian-psychological logic of an 'inside and outside', of a 'true self', a 'mind' and outside reality, body or 'nature' (Sennett 1990, 10-31).

Post-structural research, methodologically especially the post-qualitative or postmethodological attempts have focused on the former of the two positions: seeing and being seen, endlessly producing newer ways of seeing and perceiving - that is: proliferating the creating of life and societies as we go. Not as common is the discussion about not seeing and not being seen. Perhaps because partial or complete invisibility or blindness seems at odds with social scientific research - other than as a topic. Yet it is possible.

Bidisha Banerjee and Mindy Blaise did it with considering air as an invisible nonhuman research participant (Banerjee \& Blaise 2013). Nick Lee (2008) argued convincingly that a sleeping person can be an agentive research participant. John Law (2003) references David Appelbaum's (1995) book in explaining how, methodologically speaking, blindness does not indicate a loss rather than a range of different sensitivities and sensibilities (Law 2003, 10). He goes on to note that blindness "erodes the idea that by taking in the distance at a glance we can get an overview of a single reality" $(2003,10)$.

Hannah Arendt $(1978,122)$ accredits Henri Bergson as the first modern philosopher to dispute the nobility of sight. The development of Western philosophy, According to Martin Jay (1993, 186-187) relies on dependence on visual metaphors: from the shadows in Plato's cave, Augustine's divine light, to Descarte's ideas available to 'mental gaze' and the enlightenment's faith to the data of our senses. So the ocularcentric underpinning of our philosophical tradition was undeniably pervasive until the 20th century. Perspective was held as atemporal, decorporealised and transencental: same to all. Until Bergson and Nietzche came along with their fundamental critiques of oculocentrism: of the doctrine of 'immaculate perception' (Nietzsche 1961, 149), and pointed out that every viewpoint is value-laden, never detached.

Bergson distinguishes between 'imagination or intuition' and 'visual imagination'. Imagination or intuition is non-visual perception, embracing duration and continuity; as opposed to visual imagination which is a visual habit of dividing up the duration and continuity of events/life into separate things. 
"Imagination [...] signifies the absolute knowledge of a thing, which Bergson describes as an absolute coincidence with the thing's duration. Generally speaking, perception results from the difference between our duration and the durations of other things: we are able to perceive a table as a solid object only because our memory condenses the vibrations that make up that table into a manageable, solid thing." (Trifonova, 2003, 86)

What Bergson calls 'memory' is a non-visual creative force: "the negation of the given, of the present in favor of spontaneous, free creation" (Trifonova, 2003, 83). Literally speaking, when you don't see you have to imagine. Two options then become available when thinking (in a very simplified manner) with Bergson: you image visually or you imagine intuitively. The former is the path well trodden in qualitative methodology: you produce serieses of multi-modal representations, aiming for identification and recognition. The darkness propels a need to replace it with light, a need to see. The intuitive path is rather about duration: of living and breathing creatively with the darkness, of responding to it rather than representing it. But this is the path less traveled in qualitative inquiry: it's what Tim Ingold for one calls 'intellectual craftsmanship' (Ingold 2011, 240) and the path that (con)fuses theory, practice, intuition, knowledge, fact and fiction - all the while remaining something identifiable as 'research' in the end.

Through Bergson's influence on imagist poetry of the modernist movement (e.g., William Carlos Williams) we see clearly this move away from mimetic representation and toward the immediate presentation or evocation of lived experience through the arresting juxtaposition of verbal images. Stuart Aitken's 'ethnopoetics' (Aitken 2014) or Tim Ingold's 'Intellectual craftsmanship' ring many bells here. "No image can replace the intuition of duration, but many diverse images, borrowed from very different orders of things, may, by the convergence of their action, direct consciousness to the point where there is a certain intuitition to be seized". (Bergson 1947, 167)

Kullalla koristeltua lakkatyötä ei pitäisi nähdä kirkkaassa valossa, eikä katsoa yhdella silmäyksellä, vaan se tulisi jättää hämärään, heikon valon poimiessa esiin osan sieltä ja osan täältä. Työn koristeelliset ja runsaat kuviot katoavat lähes kokonaan pimeyteen, taikoen tilalleen sanoinkuvaamattomia värähtelyjä. Yössä esille asetetun lakan hehku heijastaa aaltoilevan kynttilänvalon, ilmaisten ilmavirrat, jotka aika ajoin löytävät tiensä hiljaiseen huoneeseen, ja houkuttelee ihmisen unelmoimaan. Jos lakka viedään pois, katoaa paljon tuon oudon kunttilänvalon ja lyhdyn tuomasta haavemaailmasta, tuosta aaltoilevasta, yön sydämen tahtiin lyövästä valosta. Niinkuin pienet joet juoksisivat tatamin yli keräten pieniä lammikoita sinne tänne, samoin hivelee hento, miltei huomaamaton ja epäröivä valo lakkakuvion yön pintaan. (Tanizaki, 1933/1997, 30-31.)

Seavdnjadis ja čáhppes idja

$\mathrm{Mu}$ váimmus

Niegadan ja sávan

Light and the lit object create and highlight each other. Take a lacquered and gilded decorative woodwork. It requires just the right kind of light to be seen in all its subtle glory, layers of 
varnish and gold each individually discernible as three-dimensional and as if moving, silently waving. The light required is not daylight nor a bright lightbulb but flickering and dim candlelight. Responding to whiffs of air, drafts or breath, candlelight is not stable but in constant movement. The movement of the light brings the lacquered piece alive and in turn the threedimensionally glowing piece gives away the movement of the candlelight, otherwise too subtle and vague for the human eye to catch. Bring the lacquered piece into bright sunlight and you have a flat-coloured rather than exquisitely layered object. Bring a blue plastic plate to candlelight and you have an insufficiently dim light rather than the kind of light that brings life to a surface.

The kind of knowledge produced is relative to both the object and the light - both the phenomenon under study and the conditions in which we do our work. Different combinations produce different knowledge and contest other kinds of knowledge.

\section{References}

Aitken, S. (2014). The ethnopoetics of space and transformation. Young people's engagement, activism and aesthetics. Farnham: Ashgate.

Appelbaum, D. (1995). The stop. New York: SUNY Press.

Arendt, H. (1978). The life of the mind. New York: Harcourt.

Banerjee, B., \& Blaise, M. (2013). There's something in the air: Becoming-with research practices. Cultural Studies <=> Critical Methodologies, 13(4), 240-245.

Bentham, J. (1988/1789) An introduction to the principles of morals and legislation. Prometheus Books.

Berger, J. (2009/1980). Why look at animals? London: Penguin Books.

Bergson, H. (1903/2007). An introduction to metaphysics. Mullarkey, J. \& Kolkman, M. (eds. 2007), New York: Palgrave McMillan.

Foucault, M. (1977) Discipline and punish: The birth of the prison. London: Vintage books.

Ingold, T. (2011). Being alive: Essays on movement, knowledge, and description. Abingdon: Routledge.

Jay, M. (1993). Downcast Eyes. The denigration of vision in $20^{\text {th }}$ century French thought. Berkeley: University of California Press.

Law, J. (2004). After method. Mess in social science research. London: Routledge.

Lee, N. (2008). Awake, asleep, adult, child: An a-humanist account of persons. Body Society, 14(4), 57-74.

Nietzsche, F. (1961). Thus spoke Zarathustra. London: Penguin.

Schwartzman, H.B. (1993). Ethnography in organizations. Qualitative Research Methods Series 27. Thousand Oaks, CA: SAGE.

Sennett, R. (1990). The conscience of the eye: The design and social life of cities. New York: W.W. Norton \& Co.

Trifonova, T. (2003). Matter-image or image-consciousness: Bergson contra Satre. Janus Head, 6(1), 80-114. 